\title{
Evaluation of the antimicrobial activity of bacteriocin-like inhibitory substances of enological importance produced by Oenococcus oeni isolated from wine
}

\author{
Małgorzata Lasik-Kurdyś ${ }^{1} \cdot$ Anna Sip ${ }^{2}$
}

Received: 25 July 2018 / Revised: 13 September 2018 / Accepted: 22 September 2018 / Published online: 4 October 2018

(c) The Author(s) 2018

\begin{abstract}
We experimentally determined that bacteriocin-like inhibitory substances synthetized by Oenococcus oeni may act as a natural preservative and may thus be of importance for the wine industry. An O. oeni strain isolated from wine was tested for antimicrobial activity against ten indicator lactic acid wine spoilage bacteria of enological origin from the genera Lactobacillus, Leuconostoc, and Pediococcus. A strong competition effect of $O$. oeni against all the tested indicator bacteria was noted. The antimicrobial extracellular metabolites were produced at the end of $O$. oeni's exponential growth phase and the maximum activity occurred between hours 15 and 20 of cultivation. The bioactive compounds synthetized by $O$. oeni were found to be strain-specific. Their bactericidal activity was stable at high temperatures $\left(100{ }^{\circ} \mathrm{C}, 20 \mathrm{~min}\right)$ and in low $\mathrm{pH}$ environments (with the greatest activity at $\mathrm{pH} 2-8$ ), but was totally degraded by proteolytic enzymes (pronase $\mathrm{E}$, proteinase $\mathrm{K}$, trypsin, pepsin, and $\alpha$-chymotrypsin). They can thus be classified as heat-resistant proteins active at low $\mathrm{pH}$. The dynamics of the biosynthesis and their activity were temperature-dependent, being best at $20^{\circ} \mathrm{C}$. Our results indicate that the use of an $O$. oeni starter culture with the appropriate antimicrobial potential may be a useful tool in winemaking procedures to control microbial stability and inhibit wine spoilage.
\end{abstract}

Keywords Malolactic bacteria $\cdot$ Wine microflora $\cdot$ Oenococcus oeni $\cdot$ Bacteriocin-like inhibitory substances

\section{Introduction}

Oenococcus oeni is Gram-positive, heterofermentative bacteria commonly used in winemaking. The strains perform malolactic fermentation (MLF) and are currently used in commercial starter cultures for controlled malolactic fermentation. This specific process of secondary fermentation takes place after the alcoholic fermentation and involves the bioconversion of malic acid into lactic acid. Malic acid is a

Małgorzata Lasik-Kurdyś

malgorzata.lasik@up.poznan.pl

Anna Sip

aniasip@up.poznan.pl

1 Department of Fermentation and Biosynthesis, Faculty of Food Science and Nutrition, Poznań University of Life Sciences, Wojska Polskiego 31, 60-624 Poznan, Poland

2 Department of Biotechnology and Food Microbiology, Faculty of Food Science and Nutrition, Poznań University of Life Sciences, Wojska Polskiego 48, 60-627 Poznan, Poland dicarboxylic acid, responsible for the enhanced total acidity of grape musts which contributes to the sourness of wine. Lactic acid is a monocarboxylic acid, that is weaker than malic acid, and which possesses a smoother and lighter acidity. Malolactic bioconversion thus reduces the wine's total acidity (by about $1-3 \mathrm{~g} / \mathrm{L}$ calculated as tartaric acid) and increases its $\mathrm{pH}$ (by about 0.1-0.2). Malolactic fermentation also modifies wine's aroma, reducing vegetal and herbaceous aromas while enhancing fruity aromas. Furthermore, the body and mouthfeel of the wine is also improved giving a longer aftertaste [1-5].

MLF also contributes to the microbial stability of wines. Malolactic bacteria (MLB) use up residual sugars left by yeast after alcoholic fermentation, and they also metabolize malic acid, which could also act as a carbon source for spoilage microflora. Additionally, malolactic bacteria, as lactic acid bacteria (LAB), are able to biosynthesize bacteriocins. These are low-molecular peptide compounds with antimicrobial properties secreted by some bacteria to inhibit the growth and activity of competing microorganisms [6, 7]. At present, the bacteriocins produced by LAB are perceived as 
very desirable natural food preservatives. Most LABs have been granted a qualified presumption of safety (QPS) and the bacteriocins produced by these bacteria may serve as beneficial alternatives to chemical food preservatives.

The indigenous microflora of malolactic fermentation includes bacteria of the genera: Lactobacillus, Pediococcus, Leuconostoc and Oenococcus. Some of these have already been described as synthetizing compounds with bacteriocinic properties. Lactobacillus plantarum is the best-known strain of enological origin that can produce bacteriocinin this case, various types of plantaricin: plantaricin C [8], plantaricin W [9], plantaricin C19 [10], plantaricin 423 [11, 12], plantaricin EF and JK [13, 14], plantaricin S [15], plantaricin NC8 [16], plantaricin F [17], and plantaricin $1.25 \alpha$ [18]. Pediococcus pentosaceus, which was isolated from wine [19], as well as Leuconostoc mesenteroides subsp. cremoris [20] have also been found to produce some inhibitory compounds. However, all these are strains of malolactic bacteria involved in spontaneous processes, which entail a significant risk of wine spoilage through the overproduction of undesirable metabolites, such as acids, flavour compounds, acetaldehyde, biogenic amines, ethyl carbamate [21-24]. For a controlled, dynamic and safe malolactic process, Oenococcus oeni strains are therefore often advised in the wine industry. It is thus of significant importance to know whether this microorganism can also produce antimicrobial compounds. The selection of such strains for industrial use could help in controlling microbial activity and differentiation during the vinification process.

To our knowledge, only one research group [25] testing for the presence of bacteriocin-encoding genes in lactic acid bacteria examined strains of Oenococcus oeni. We have not found any research directly related to the biosynthesis of antimicrobial compounds by either Oenococcus oeni isolated from wine or by commercial starter cultures that include $O$. oeni. The objective of our study was thus to find and characterize the bacteriocin-like inhibitory substances (BLIS) synthetized by an $O$. oeni wine isolate. The activity of the bioactive metabolites synthetized by $O$. oeni was evaluated against ten indicator bacteria of enological origin belonging to wine spoilage MLB of the genera Lactobacillus, Leuconostoc, and Pediococcus.

\section{Materials and methods}

\section{Microorganisms}

One isolate of Oenococcus oeni was tested for synthesis of bacteriocin-like inhibitory substances (BLIS). Ten other strains of malolactic bacteria isolated from wine were used in the experiments as indicator microorganisms. All the strains, listed in the Table 1, are of enological origin and belong to the Spanish Culture Type Collection (CECT). The strains were stored in a Cryobank (Bacteria storage system, MAST Diagnostica) at $-20^{\circ} \mathrm{C}$. Prior to the tests, the strains were defrosted and passaged twice in MRS broth medium under anaerobic conditions (Anaxomat, temp. $30^{\circ} \mathrm{C}, 24 \mathrm{~h}$ ).

\section{Supernatants}

A $2 \% \mathrm{v} / \mathrm{v}$ inoculum of Oenococcus oeni CECT $217 \mathrm{~T}$ was used and cultures were carried out in MRS broth medium at pH 6.2 under anaerobic conditions (Anaxomat), without $\mathrm{pH}$ regulation at $30{ }^{\circ} \mathrm{C}$ for $20 \mathrm{~h}$. The supernatants we obtained after centrifugation $(5500 \mathrm{~g}, 10 \mathrm{~min})$ were analyzed for their antibacterial activity against ten indicator microorganisms. Two types of supernatants were tested: (1) native supernatant (directly after centrifugation), and (2) treated supernatant (after $\mathrm{pH}$ neutralisation and catalase treatment). The native supernatant was applied as indicator of the activity of the total extracellular metabolites synthetized by the tested strain. The treated supernatant was neutralized to $\mathrm{pH} 6.5$ using $1 \mathrm{~N} \mathrm{NaOH}$, to eliminate the antimicrobial activity of the organic acids, and was treated with $68,000 \mathrm{IU} / \mathrm{ml}$ catalase to degrade hydrogen peroxide. Both types of supernatants were evaluated separately.
Table 1 Bacteria wine isolates used in this study

\begin{tabular}{|c|c|}
\hline Oenococcus oeni CECT $217 \mathrm{~T}$ & $\begin{array}{l}\text { Indicator microorganisms: } \\
\text { Lactobacillus hilgardii CECT } 4786 \mathrm{~T} \\
\text { Lactobacillus hilgardii CECT } 4681 \\
\text { Lactobacillus brevis CECT } 4121 \mathrm{~T} \\
\text { Lactobacillus brevis } \text { CECT } 216 \\
\text { Lactobacillus buchneri } \text { CECT } 4111 \mathrm{~T} \\
\text { Lactobacillus buchneri CECT } 4674 \\
\text { Leuconostoc mesenteroides CECT } \\
219 \mathrm{~T} \\
\text { Leuconostoc mesenteroides } \text { CECT } \\
394 \\
\text { Pediococcus pentosaceus } \text { CECT } \\
4695 \mathrm{~T} \\
\text { Pediococcus pentosaceus } \text { CECT } 923\end{array}$ \\
\hline
\end{tabular}




\section{Evaluation of antimicrobial activity}

Inhibition zones evaluation Twenty microliter samples of liquid cultures of Oenococcus oeni CECT 217T (including live cells) or their supernatants (with no live cells) were plotted on Petri dishes with MRS agar medium (1\% agar) inoculated with $10^{6} \mathrm{cfu} / \mathrm{ml}$ of indicator malolactic bacteria isolates. The plates were incubated under anaerobic conditions at $30{ }^{\circ} \mathrm{C}$ for $14 \mathrm{~h}$. After incubation, the inhibition zones were evaluated by a computer scanning system (MultiScanBase v14.02).

Critical dilutions method The supernatants were diluted twice using $100 \mathrm{mM}$ phosphate buffer with $\mathrm{pH}$ 6.5. The diluted samples were then plotted on Petri dishes with MRS agar medium ( $1 \%$ agar) inoculated with $10^{6} \mathrm{cfu} / \mathrm{ml}$ of indicator malolactic bacteria isolates. The plates were incubated under anaerobic conditions at $37^{\circ} \mathrm{C}$ for $18-20 \mathrm{~h}$. Antimicrobial activity was expressed in $\mathrm{AU} / \mathrm{ml}$ (the reciprocal of the highest dilution of the sample) which give clear inhibition zones (those zones with diameters over $2 \mathrm{~mm}$ ).

\section{Physiochemical characteristics of the synthetized BLIS}

The supernatants with the highest bacteriostatic activity were treated with enzymes, temperature, and $\mathrm{pH}$ to evaluate their physiochemical nature.

For enzymes' treatment The supernatants were incubated for $2 \mathrm{~h}$ with the selected enzymes (each of the enzyme separately) such as pronase E, proteinase $\mathrm{K}$, pepsin, trypsin, $\alpha$-chymotrypsin, $\alpha$-amylase, lysozyme, catalase and lipase (Sigma). The applied concentration of the tested enzymes was $1 \mathrm{mg} / \mathrm{ml}$. After incubation, the antibacterial activity of the supernatants was evaluated.

For temperature treatment The supernatants were heated at 80 and $100{ }^{\circ} \mathrm{C}$ for 10,20 and $30 \mathrm{~min}$ and at $121{ }^{\circ} \mathrm{C}$ for $15 \mathrm{~min}$. After incubation, the antibacterial activity of the supernatants was evaluated.

For $\mathrm{pH}$ treatment The supernatants' $\mathrm{pH}$ was adjusted from 2.0 to $10.0(\Delta=0.5)$ using $1 \mathrm{~N} \mathrm{NaOH}$ and $1 \mathrm{~N} \mathrm{HCl}$. This was incubated at room temperature for $2 \mathrm{~h}$. After incubation, the $\mathrm{pH}$ of the samples was regulated back to 6.5 and the antibacterial activity of the supernatants was evaluated.

After these treatments, the antibacterial activities of the supernatants were evaluated using the critical dilution method and expressed as AU/ml.

\section{Dynamics of BLIS biosynthesis}

The MRS broth medium was inoculated with $2 \%(\mathrm{v} / \mathrm{v})$ of overnight $O$. oeni culture. The incubation was conducted without $\mathrm{pH}$ regulation at temperatures of $10,20,30$, and $37^{\circ} \mathrm{C}$ for $60 \mathrm{~h}$. During incubation, at $5,10,15,20,25,30$,
35 , and $60 \mathrm{~h}$, samples were taken to evaluate antimicrobial activity using the critical dilution method. The results were expressed as AU/ml.

\section{Influence of BLIS on Pediococcus pentosaceus growth}

Having undergone $O$. oeni incubation under anaerobic conditions $\left(30^{\circ} \mathrm{C}, 24 \mathrm{~h}\right)$, the supernatants were centrifuged (5500 g, $10 \mathrm{~min}$ ), and incubated at $80{ }^{\circ} \mathrm{C}$ for $10 \mathrm{~min}$ and sterilized by membrane filters (Millex GV, $0.22 \mu \mathrm{m}$, Millipore) to eliminate the activity of proteolytic enzymes and remove the remaining cells. We refer to these supernatants as active extracts (AE). MRS broth medium was inoculated with $10^{3} \mathrm{cfu} / \mathrm{ml}$ of Pediococcus pentosaceus CECT $4695 \mathrm{~T}$ and incubated at $30{ }^{\circ} \mathrm{C}$ for $4 \mathrm{~h}$. Then, 200,400 , and $800 \mathrm{AU} /$ $\mathrm{ml}$ of $\mathrm{AE}$ were introduced into the growing culture, which was incubated for a further $20 \mathrm{~h}$. Every $4 \mathrm{~h}$, samples were evaluated for the number of $P$. pentosaceus bacteria (as cfu/ $\mathrm{mL}$ ) during growth in presence of the BLIS. A culture without BLIS (0 AU/ml) was monitored as a control.

\section{Human/animal rights}

This article does not contain any studies with human or animal subjects.

\section{Results and discussion}

\section{Antimicrobial activity of Oenococcus oeni isolate}

To date, a few studies have been carried out on the antimicrobial compounds synthetized by bacteria of enological origin and have presented their spectrum of inhibition activity, like diverse bacteriostatic potential against different indicator strains from the group of wine or general food spoilage bacteria [2, 11, 17, 19, 20, 26, 27]. However, O. oeni strains have been used in these studies only as indicator microorganisms showing differential sensitivity to these bactericidal metabolites, and not as a producer. In our study, O. oeni, being the most important microorganism in the malolactic process, was evaluated for its production of antimicrobial substances including BLIS productions.

Evaluation of the antimicrobial activity of extracellular metabolites was performed using liquid medium that had undergone cultivation with Oenococcus oeni CECT 217T (the medium containing live $O$. oeni cells). This was done to estimate the antagonistic potential of the $O$. oeni strain and its metabolites against ten indicator malolactic bacteria also isolated from wine. The indicator microorganisms (bacteria of the genera Lactobacillus, Leuconostoc, and Pediococcus) were chosen as elements of the native wine flora, that take part in spontaneous malolactic fermentation and which 
potentially present the dangers of wine spoilage. In all cases, intense inhibition zones ( $\geq 10 \mathrm{~mm}$ ) were observed, with the highest bactericidal activity (a $14 \mathrm{~mm}$ inhibition zone) noted

Table 2 Antimicrobial activity of Oenococcus oeni CECT 217T and their exogenous metabolites against ten indicator malolactic bacteria

\begin{tabular}{|c|c|c|c|}
\hline $\begin{array}{l}\text { Indicator } \\
\text { microorganisms }\end{array}$ & $\begin{array}{l}\text { Liquid } O . \text { oeni } \\
\text { culture }\end{array}$ & $\begin{array}{l}\text { Native superna- } \\
\text { tants }\end{array}$ & $\begin{array}{l}\text { Treated super- } \\
\text { natants (pH 6.5, } \\
\text { catalase treat- } \\
\text { ment) }\end{array}$ \\
\hline Lactobacil- & + & - & - \\
\hline lus hilgardii & + & - & - \\
\hline СЕCT 4786T & + & \pm & - \\
\hline Lactobacil- & + & \pm & - \\
\hline lus hilgardii & + & - & - \\
\hline CECT 4681 & + & - & - \\
\hline Lactobacillus & ++ & + & \pm \\
\hline brevis CECT & ++ & ++ & + \\
\hline $4121 \mathrm{~T}$ & ++ & ++ & + \\
\hline $\begin{array}{l}\text { Lactobacillus } \\
\text { brevis CECT } \\
216\end{array}$ & ++ & + & \pm \\
\hline $\begin{array}{l}\text { Lactobacil- } \\
\text { lus buchneri } \\
\text { CECT } 4111 \mathrm{~T}\end{array}$ & & & \\
\hline $\begin{array}{l}\text { Lactobacil- } \\
\text { lus buchneri } \\
\text { CECT } 4674\end{array}$ & & & \\
\hline $\begin{array}{l}\text { Leuconostoc } \\
\text { mesenteroides } \\
\text { CECT 219T }\end{array}$ & & & \\
\hline $\begin{array}{l}\text { Leuconostoc } \\
\text { mesenteroides } \\
\text { CECT } 394\end{array}$ & & & \\
\hline $\begin{array}{l}\text { Pediococcus } \\
\text { pentosaceus } \\
\text { CECT } 4695 \mathrm{~T}\end{array}$ & & & \\
\hline $\begin{array}{l}\text { Pediococcus } \\
\text { pentosaceus } \\
\text { CECT } 923\end{array}$ & & & \\
\hline
\end{tabular}

- no antagonistic activity, \pm weak bacteriostatic activity (inhibition zone with dia $<10 \mathrm{~mm}$ ), + strong bacteriostatic activity (inhibition zone with dia $10-14 \mathrm{~mm}$ ), ++ very strong bacteriostatic activity (inhibition zone with dia $>14 \mathrm{~mm}$ ) against Leuconostoc mesenteroides and Pediococcus pentosaceus strains (Table 2).

To identify the antimicrobial substances as exogenous metabolites released by the $O$. oeni isolate, the bacterial biomass was separated and native, cell-free supernatants were analyzed. Generally, after removing the alive $O$. oeni cells, the inhibition activity registered was significantly lower. Leuconostoc mesenteroides and Pediococcus pentosaceus remained notably sensitive to the exogenous metabolites active in the supernatants (with inhibition zones of $\geq 10 \mathrm{~mm}$ ). Weak growth inhibition was observed for $\mathrm{Lac}$ tobacillus brevis. No antagonistic properties of extracellular metabolites were observed against Lactobacillus hilgardii and Lactobacillus buchneri (Table 2).

Next, the native supernatants were neutralized (to eliminate the antimicrobial effect of organic acids) and treated with catalase (to degrade hydrogen peroxide). This additional treatment was necessary to ensure that no lactic acid or $\mathrm{H}_{2} \mathrm{O}_{2}$ (LAB metabolites with inhibitory properties) affected the growth of the indicator microorganism [28]. Evaluation of these supernatants showed that there were some BLIS active against Leuconostoc mesenteroides and Pediococcus pentosaceus among the bioactive metabolites synthetized by $O$. oeni isolate (Table 3 ).

The presence of live $O$. oeni cells caused strong inhibition in the growth of all the indicator microorganisms. This suggests a strong competition effect and implies that, during malolactic fermentation, $O$. oeni has great potential to maintain prevalence and to control the process. Besides, some of the extracellular metabolites can cleave to the microbial cell wall and in this case they could be removed together with the alive cells. However, when evaluating the native supernatants without the live $O$. oeni cells which can serve as a model of the storage and maturation time that follows malolactic fermentation, the antimicrobial activity was found to be strain-dependent and had a significantly lower intensity (Table 2).

Next, the dynamic of the exogenous biosynthesis of metabolites by $O$. oeni $C E C T 217 \mathrm{~T}$, as well as the maximum activity of these antimicrobial compounds, were
Table 3 Maximal activity of exogenous metabolites of Oenococcus oeni CECT $217 \mathrm{~T}$ against selected malolactic bacteria isolates

\begin{tabular}{|c|c|c|c|c|}
\hline \multirow[t]{2}{*}{ Selected indicator MLB isolates } & \multicolumn{2}{|c|}{ All exogenous metabolites } & \multicolumn{2}{|l|}{ BLIS } \\
\hline & $\begin{array}{l}\text { Max activity } \\
(\mathrm{AU} / \mathrm{ml})\end{array}$ & $\begin{array}{l}\text { Cultivation } \\
\text { time (h) }\end{array}$ & $\begin{array}{l}\text { Max activity } \\
(\mathrm{AU} / \mathrm{ml})\end{array}$ & $\begin{array}{l}\text { Cultiva- } \\
\text { tion time } \\
\text { (h) }\end{array}$ \\
\hline Lactobacillus brevis CECT $4121 \mathrm{~T}$ & 200 & 15 & - & - \\
\hline Lactobacillus brevis CECT 216 & 200 & 15 & - & - \\
\hline Leuconostoc mesenteroides CECT 219T & 800 & 15 & 200 & 15 \\
\hline Leuconostoc mesenteroides CECT 394 & 1600 & 15 & 800 & 15 \\
\hline Pediococcus pentosaceus CECT $4695 \mathrm{~T}$ & 3200 & 20 & 1600 & 20 \\
\hline Pediococcus pentosaceus CECT 923 & 1600 & 15 & 200 & 15 \\
\hline
\end{tabular}


considered. We observed that the metabolites are produced at the end of $O$. oeni's exponential growth phase and that the maximum activity fell between hours 15 and 20 of cultivation (Table 3). This observation is in line with those of other authors, who showed that biosynthesis of bacteriocins begins at the end of the exponential phase $[19,26,27,29$, $30]$ or at the beginning of the stationary phase $[17,19]$ of the producer's growth.

The maximum antimicrobial activity of the secreted metabolites was strain-specific and ranged from 200 to $3200 \mathrm{AU} / \mathrm{ml}$. The highest bactericidal activity was observed against Pediococcus pentosaceus CECT 4695T (Table 3). The BLIS synthetized by $O$. oeni isolate were also characterized with high specific activities. The antagonistic properties of 800 and $1600 \mathrm{AU} / \mathrm{ml}$ were shown against Leuconostoc mesenteroides CECT 394 and Pediococcus pentosaceus CECT 4695T, respectively (Table 3).

To date, only one research group has presented data on the antimicrobial activity of $O$. oeni strains. Knoll et al. [25] screened a broad spectrum of lactic acid bacteria of enological origin for bacteriocin-encoding genes. Among the strains they evaluated were strains of $O$. oeni (wine isolates and commercial starter cultures), which were found to be able to inhibit wine-associated bacteria such as Lactobacillus hilgardii, Lactobacillus plantarum, Lactobacillus brevis, Lactobacillus paracasei, Lactobacillu pentosus, Lactobacillus fermentum, Lactococcus mesenteroides, Pediococcus pentosaceus, as well as Listeria monocytogenes and Enterococcus faecalis. The inhibiton zones were in the range of $1-5 \mathrm{~mm}$ in a colony-overlay test. However, this very useful report focused on the genomic site of bacteriocin production mechanisms, and not on the characteristics of these active metabolites.

\section{Physiochemical characteristics of the synthetized BLIS}

A high sensitivity of different bacteriocin substances to proteolytic enzymes has been noted by researchers evaluating their physiochemical properties [19, 26, 27]. The active metabolites produced in our study by Oenococcus oeni were also sensitive to proteolytic enzymes, with their complete inactivation being observed after treatment with pronase $\mathrm{E}$, proteinase $\mathrm{K}$, trypsin, pepsin and $\alpha$-chymotrypsin. On the other hand, no changes were noted in antimicrobial activity when other enzymes (such as $\alpha$-amylase, lysozyme, catalase, and lipase) were applied (Table 4). This may indicate that the antimicrobial activity of the tested $O$. oeni metabolites is relevant to the proteinaceous part of the bacteriocin molecules. Rojo-Bezares et al. [27] and Navarro et al. [26] also studied the possibility of using lysozyme in the microbial control of malolactic process and to increase the microbial stability of wine. The active metabolites they investigated,
Table 4 Influence of enzyme, temperature and $\mathrm{pH}$ on the antimicrobial activity of bacteriocin-like inhibitory metabolites of Oenococcus oeni CECT 217T

\begin{tabular}{ll}
\hline Treatment & $\begin{array}{l}\text { Activity } \\
\text { (AU/ } \\
\mathrm{ml})^{\mathrm{a}}\end{array}$ \\
\hline Before treatment & 1600 \\
Enzymes & 0 \\
Pronase E & 0 \\
Proteinase K & 0 \\
Trypsin & 0 \\
Pepsin & 0 \\
$\alpha$-chymotrypsin & 1600 \\
$\alpha$-amylase & 1600 \\
Lysozyme & 1600 \\
Catalase & 1600 \\
Lipase & \\
Heating & 1600 \\
10 min. $80^{\circ} \mathrm{C}$ & 1600 \\
20 min. $80^{\circ} \mathrm{C}$ & 1600 \\
30 min. $80^{\circ} \mathrm{C}$ & 1600 \\
10 min. $100{ }^{\circ} \mathrm{C}$ & 1600 \\
20 min. $100{ }^{\circ} \mathrm{C}$ & 800 \\
30 min. $100{ }^{\circ} \mathrm{C}$ & 0 \\
15 min. $121^{\circ} \mathrm{C}$ & \\
pH & 1600 \\
$2.0-8.0(\Delta=0.5)$ & 400 \\
$8.5-9.5$ & 200 \\
10.0 & \\
\hline & \\
\hline
\end{tabular}

${ }^{a}$ Activity evaluated by critical dilution method against Pediococcus pentosaceus CECT $4695 \mathrm{~T}$

like those produced in our study, remained stable when treated with lysozyme, which clearly shows that the combination of antimicrobial enzyme (lysozyme) and antimicrobial metabolites synthetized by bacteria of enological origin, especially $O$. oeni, may be useful in vinification procedures for controlling malolactic fermentation in wineries, and also as a method of reducing sulfitation dosages.

We next tested the antimicrobial activity under different heating regimes. The bioactive metabolites of $O$. oeni showed good resistance to increased temperatures. Conditions such as $100^{\circ} \mathrm{C}$ for $20 \mathrm{~min}$ did not alter the antibacterial potential of the tested metabolites. Longer exposure $\left(100^{\circ} \mathrm{C}\right.$ for $30 \mathrm{~min}$ ) significantly decreased metabolite activity from 1600 to $800 \mathrm{AU} / \mathrm{ml}$. Complete loss of antimicrobial activity was observed after $15 \mathrm{~min}$ at $121^{\circ} \mathrm{C}$ (Table 4). This relatively high thermostability (for proteinaceous compounds) of bacteriocinic substances may arise from their low-complexity structure (perhaps due to the absence of a tertiary structure) or from the presence of covalent bonds that help stabilize the protein globular structure [26, 31].

The bioactive compounds we examined, like most bacteriocins and bacteriocin-like substances described in the literature, were stable over a wide $\mathrm{pH}$ range. After $2 \mathrm{~h}$ of incubation in environments with $\mathrm{pH}$ values ranging from 2.0 to 8.0 , no changes in the antibacterial activity were detected. 
The metabolites lost their bacteriostatic properties at $\mathrm{pH}$ values above 8.0. At $\mathrm{pH} 10$, only very low activity was seen (200 AU/ml) (Table 4).

After these tests, it can be posited that the bioactive metabolites synthetized by Oenococcus oeni CECT $217 \mathrm{~T}$ are heat-resistant proteins with their highest activity at low $\mathrm{pH}$ values. Very similar properties, such as high protease sensitivity, thermostability, thermoresistance and higher activity at lower $\mathrm{pH}$ values, have been also reported by authors studying other bacteriocins, such as pediocin PA-1 [32], pediocin N5p [19], brevicin 37, caseicin 80 and lactarin F [33, 34], plantaricin A [35], plantaricin S and T [30], plantaricin C [36], plantaricin D [37], plantaricin F [38], and others [19, 20, 26, 27, 31]. Navarro et al. [26] and Rojo-Bezares [27] have additionally stated that bacteriocin activity remained stable at storage temperatures $\left(4\right.$ and $\left.-20^{\circ} \mathrm{C}\right)$, and following treatment with organic solvents, such as chloroform and ethanol.

\section{Dynamics of BLIS biosynthesis at different temperatures}

The efficiency of BLIS biosynthesis was monitored at temperatures ranging from 10 to $37^{\circ} \mathrm{C}$. Bacteriocin-like inhibitory substances were synthetized by the $O$. oeni isolate at all tested temperatures, but with the effectiveness of biosynthesis strongly depending on the temperature (Fig. 1). The highest biosynthesis dynamics and the greatest activity on the part of the metabolites produced were seen at $20^{\circ} \mathrm{C}$. The highest activity (3200 AU/ml) was noted from hour 20 of cultivation onwards, and did not change until hour 60 . The lowest level of synthesis was recorded at $37^{\circ} \mathrm{C}(100-200$ $\mathrm{AU} / \mathrm{ml})$. It was also observed that the incubation temperature determined the stability of the bacteriocin-like metabolites that we tested. At 10 and $20^{\circ} \mathrm{C}$, the activity peaked in hour 20 and thereafter maintained a stable level. On the other hand, a gradual decrease in bactericidal activity was seen at higher temperatures (Fig. 1).

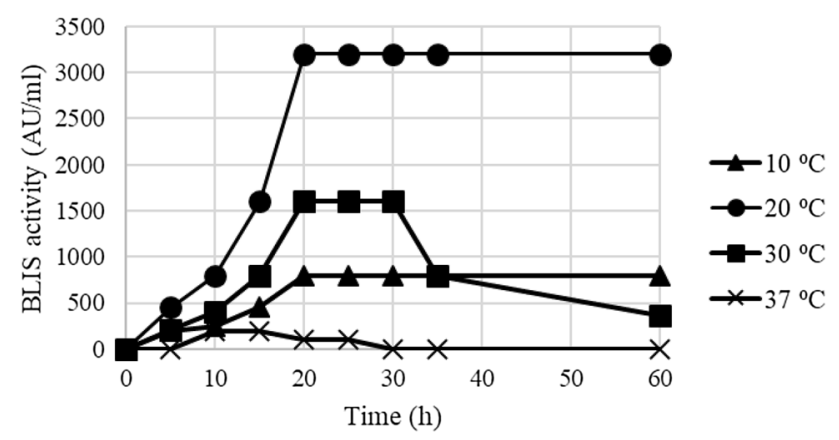

Fig. 1 Dynamics of BLIS biosynthesis at different temperatures; indicator strain: Pediococcus pentosaceus CECT 4695T
Navarro et al. [26] evaluated the dynamics of bacteriocin production by Lactobacillus plantarum at 25 and $30{ }^{\circ} \mathrm{C}$. In that study, the temperature also affected the rate of bacteriocin biosynthesis. The detectable antimicrobial activity was noted to be faster when synthetized at $30^{\circ} \mathrm{C}$. The beginning of the biosynthesis process was observed at the end of the exponential phase and the beginning of the stationary phase and the activity remained stable for the following next $10 \mathrm{~h}$.

\section{Effect of BLIS on the growth of Pediococcus pentosaceus}

To evaluate the effect of BLIS, an indicator microorganism, Pediococcus pentosaceus CECT 4695 T was cultivated in MRS medium for $4 \mathrm{~h}$ and thereon 200, 400, and $800 \mathrm{AU} / \mathrm{ml}$ of BLIS active extracts were added to the growing culture. It was observed that the addition of the BLIS to the culture environment significantly altered the growth dynamic of the bacteria. Even the lowest dosage of BLIS (200AU/ml) resulted in a significant decrease in the growth dynamics of Pediococcus pentosaceus (Fig. 2).

The application of $400-800 \mathrm{AU} / \mathrm{ml}$ of BLIS led to a reduction of 1-2 log units during first four hours of incubation, and afterwards halted the growth of these bacteria, keeping their numbers stable. Similarly, a significant decline in the growth curve was recorded when the BLIS synthetized by Leuconostoc mesenteroides subsp. cremoris was added to the growth medium of Lactobacillus delbrueckii [20].

\section{Conclusion}

In recent years in the wine industry, special attention has been paid to the need for alternative preservatives to replace the traditional sulfitation procedure. Some alternatives have been investigated, and there have been indication that it might be possible to use natural antimicrobial agents such

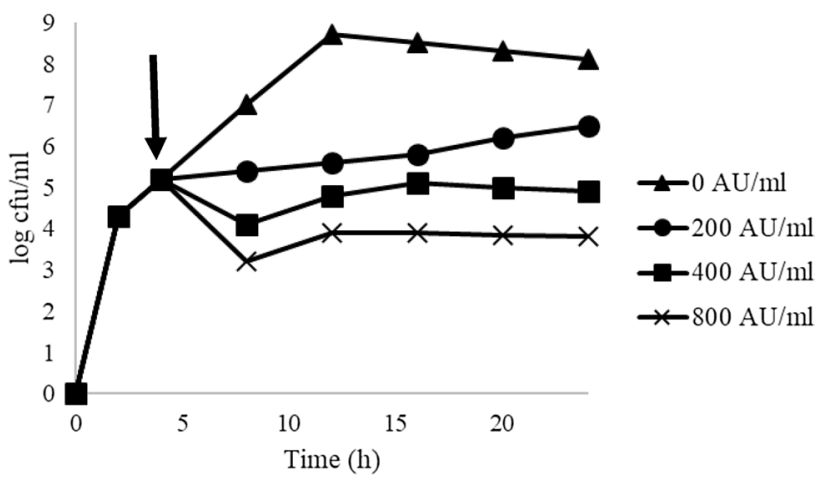

Fig. 2 Influence of BLIS on Pediococcus pentosaceus CECT 4695T growth (arrow indicate the time of $\mathrm{AE}$ addition, $0 \mathrm{AU} / \mathrm{ml}$ - without BLIS addition, as a control culture) 
as lysozyme, nisin, lacticin, polyphenols, or bovine lactoferrin [26, 29, 39-41]. As products of natural origin, these are perceived as much more "friendly" than sulfities, but they nonetheless remain materials added to the process, and thus classified as food additives. They have also been found to inhibit not only unfavorable wine microflora but also the growth and activity of $O$. oeni-bacteria essential to the successful malolactic process.

In our study, we found that $O$. oeni itself is capable of synthetizing certain protein compounds with antimicrobial activity, these can be classified as bacteriocin-like inhibitory substances. This is the first study to present and evaluate the BLIS synthetized by the O.oeni wine isolate, so further investigations should be undertaken to screen other strains and to assess their growth inhibitory activities, which may be of enological importance under winemaking conditions.

The use of a bacteriocin-producing $O$. oeni starter culture may prove to be a good enological practice for the wine industry. Our promising results suggest that the use of an $O$. oeni starter culture with the appropriate antimicrobial potential may not only help malolactic bioconversion to succeed without undesirable metabolites, but may also maintain microbial stability and prevent wine spoilage problems.

Acknowledgements We would like to acknowledge Professor Cristina Reguant Miranda from Universitat Rovira i Virgili (Spain) for kindly facilitating of the strains from Spanish Culture Type Collection for this study. This research was realized within the financial support of research grant obtained from the National Research Centre in Polandproject No NN312 206,036.

\section{Compliance with ethical standards}

Conflict of interest The authors declare that they have no conflict of interest.

Compliance with ethics requirements This article does not contain any studies with human or animal subjects.

Open Access This article is distributed under the terms of the Creative Commons Attribution 4.0 International License (http://creativeco mmons.org/licenses/by/4.0/), which permits unrestricted use, distribution, and reproduction in any medium, provided you give appropriate credit to the original author(s) and the source, provide a link to the Creative Commons license, and indicate if changes were made.

\section{References}

1. Henick-Kling T (1995) Control of malo-lactic fermentation in wine: energetics, flavour modification and methods of starter culture preparation. J Appl Bacteriol Symp Suppl 79:29-37

2. Lonvaud-Funel A, Joyeux A (1993) Antagonism between lactic acid bacteria of wines: inhibition of Leuconostoc oenos by Lactobacillus plantarum and Pediococcus pentosaceus. Food Microbiol 10:411-419
3. Davis CR, Wibowo D, Eschenbruch R, Lee TH, Fleet GH (1985) Practical implications of malolactic fermentation in wine. J Appl Bacteriol 63:513-521

4. Wibowo D, Eschenbruch R, Davis CR, Fleet GH, Lee TH (1985) Occurrence and growth of lactic acid bacteria in wine: a review. Am J Enol Vitic 36:302-313

5. Versari A, Parpinello GP, Cattaneo M (1999) Leuconostoc oenos and malolactic fermentation in wine: a review. J Ind Microbiol Biotechnol 23:447-455

6. Cleveland J, Montville TJ, Nes IF, Chikindas ML (2001) Bacteriocins: safe, natural antimicrobials for food preservation. Int J Food Microbiol 71:1-20

7. Klaenhammer TR (1988) Bacteriocins of lactic acid bacteria. Biochimie 70:337-349

8. Turner DL, Brennan L, Meyer HE, Lohaus C, Siethoff C, Costa HS, Gonzalez B, Santos H, Suarez JE (1999) Solution structure of plantaricin C, a novel lantibiotic. Eur J Biochem 264:833-839

9. Holo H, Jeknic Z, Daeschel M, Stevanovic S, Nes IF (2001) Plantaricin $\mathrm{W}$ from Lactobacillus plantarum belong to a new family of two-peptide lantibiotics. Microbiol 147:643-651

10. Atrih A, Rekhif N, Moir AJ, Lebrihi A, Lefebvre G (2001) Mode of action, purification and amino acid sequence of plantaricin $\mathrm{C} 19$, an anti-Listeria bacteriocin produced by Lactobacillus plantarum C19. Int J Food Microbiol 68:93-104

11. Nel HA, Bauer R, Wolfaardt GM, Dicks LM (2002) Effect of bacteriocins pediocin PD-1, plantaricin 423 and nisin on biofilms of Oenococcus oeni on a stainless steel surface. Am J Enol Vitic 53:191-196

12. Van Reenen CA, Dicks LM, Chikindas ML (1998) Isolation, purification and partial characterization of plantaricin 423 , a bacteriocin produced by Lactobacillus plantarum. J Appl Microbiol 84:1131-1137

13. Moll GN, van den Akker E, Hauge HH, Nissen-Meyer J, Nes IF, Konings WN, Driessen AJ (1999) Complementary and overlapping selectivity of the two-peptide bacteriocins plantaricin EF and JK. J Bacteriol 181:4848-4852

14. Anderssen EL, Diep BD, Nes IF, Eijsink VG, Nissen-Meyer J (1998) Antagonistic activity of Lactobacillus plantarum C11: two new two-peptide bacteriocins, plantaricins EF and JK, and the induction factor plantaricin A. Appl Environ Microbiol 64:2269-2272

15. Stephens SK, Floriano B, Cathcart DP, Bayley SA, Witt VF, Jimenez-Diaz R, Warner PJ, Ruiz-Barba JL (1998) Molecular analysis of the locus responsible for production of plantaricin $\mathrm{S}$, a two-peptide bacteriocin produced by Lactobacillus plantarum LPCO10. Appl Environ Microbiol 64:1871-1877

16. Maldonado A, Ruiz-Barba JL, Jimenez-Diaz R (2003) Purification and genetic characterization of plantaricin NC8, a novel coculture-inducible two-peptide bacteriocin from Lactobacillus plantarum NC8. App Environ Microbiol 69:383-389

17. Poynter MJB, Brown KA, Hayasaka SS (1997) Factors affecting the production of an antimicrobial agent, plantaricin F, by Lactobacillus plantarum BF001. Lett Appl Microbiol 24:159-165

18. Remiger A, Eijsink VGH, Ehrmann MA, Sletten K, Nes IF, Vogel RF (1999) Purification and partial amino acid sequence of plantaricin $1.25 \alpha$ and $1.25 \beta$, two bacteriocins produced by Lactobacillus plantarum TMW1.25. J Appl Microbiol 86:1053-1058

19. Strasser de Saad AM, Manca de Nadra M (1993) Characterization of bacteriocin produced by Pediococcus pentosaceus from wine. J Appl Bacteriol 74:406-410

20. Yurdugul S, Bozoglu F (2002) Studies on an inhibitor produced by lactic acid bacteria of wines on the control of malolactic fermentation. Eur Food Res Technol 215:38-41 
21. Smit AY, du Toit M (2013) Evaluating the influence of malolactic fermentation inoculation practices and ageing on lees on biogenic amine production in wine. Food Bioprocess Technol 6:198-206

22. Lonvaud-Funel A (2001) Biogenic amines in wines: role of lactic acid bacteria. FEMS Microbiol Lett 199:9-13

23. Masque MC, Soler M, Zaplana B, Franquet R, Rico S, Elorduy X, Puig A, Bertran E, Capdevila F, Palacios AT, Romero SV, Heras JM, Krieger-Weber S (2011) Ethyl carbamate content in wines with malolactic fermentation induced at different points in the vinification process. Ann Microbiol 61:199-206

24. Osborne JP, de Ordona RM, Pilone GJ, Liu SQ (2000) Acetaldehyde metabolism by wine lactic acid bacteria. FEMS Microbiol Lett 191:51-55

25. Knoll C, Divol B, du Toit M (2008) Genetic screening of lactic acid bacteria of oenological origin for bacteriocin-encodes genes. Food Microbiol 25:983-991

26. Navarro L, Zarazaga M, Saenz J, Ruiz-Larrea F, Torres C (2000) Bacteriocin production by lactic acid bacteria isolated from Rioja red wines. J Appl Microbiol 88:44-51

27. Rojo-Bezares B, Saenz Y, Navarro L, Zarazaga M, Ruiz-Larrea F, Torres C (2007) Coculture-inducible bacteriocin activity of Lactobacillus plantarum strain J23 isolated from grape must. Food Microbiol 24:482-491

28. Dahiya RS, Speck ML (1968) Hydrogen peroxide formation by Lactobacilli and its effect on Staphylococcus aureus. J Dairy Sci 51:1568-1572

29. Garcia-Ruiz A, Requena T, Pelaez C, Bartolome B, MorenoArribas MV, Martinez-Cuesta MC (2013) Antimicrobial activity of lacticin 3147 against oenological lactic acid bacteria. Combined effect with other antimicrobial agents. Food Contr 32:477-483

30. Jimenez-Diaz R, Rios-Sanchez RM, Desmazeaud M, Ruiz-Barba JL, Piard JC (1993) Plantaricins S and T, two new bacteriocins produced by Lactobacillus plantarum LPCO 10 isolated from a green olive fermentation. Appl Environ Microbiol 59:1416-1424

31. De Vuyst L, Vandamme EJ (1994) Antimicrobial potential of lactic acid bacteria. In: De Vuyst L, Vandamme EJ (eds) Bacteriocins of Lactic acid bacteria. Blackie Academie \& Professional, Glasgow
32. Gonzalez CF, Kunka BS (1987) Plasmid-associated bactetriocin production and sucrose fermentation in Pediococcus acidilactici. Appl Environ Microbiol 53:2534-2538

33. Rammelsberg M, Radler F (1990) Antibacterial polypeptides of Lactobacillus species. J Appl Bacteriol 69:177-184

34. Muriana PM, Klaenhammer TR (1987) Conjugal transfer of plasmid-encoded determinants for bacteriocin production and immunity in Lactobacillus acidophilus 11088. Appl Environ Microbiol 57:553-560

35. Daeschel MA, McKenney MC, McDonald LC (1990) Bacteriocidal activity of Lactobacillus plantarum C-11. Food Microbiol 7:91-98

36. Gonzalez B, Arca P, Mayo B, Suarez JE (1994) Detection, purification and partial characterization of plantaricin $\mathrm{C}$, a bacteriocin produced by a Lactobacillus plantarum strain of dairy origin. Appl Environ Microbiol 60:2158-2163

37. Franz CMAP, Du Toit M, Olasupo NA, Schillinger U, Holzaphel WH (1998) Plantaricin D, a bacteriocin produced by Lactobacillus plantarum BFE 905 from ready-to-eat salad. Lett Appl Microbiol 26:231-235

38. Fricourt BV, Barefoot SF, Testin RF, Haysaska SS (1994) Detection and activity of plantaricin $\mathrm{F}$, an antimicrobial substance from Lactobacillus plantarum BF001 isolated from processed chant catfish. J Food Protect 57:698-702

39. Rojo-Bezares B, Saenz Y, Zarazaga M, Torres C, Ruiz-Larrea F (2007) Antimicrobial activity of nisin against Oenococcus oeni and other wine bacteria. Int J Food Microbiol 116:32-36

40. Enrique M, Manzanares P, Yuste M, Martinez M, Valles S, Mar$\cos$ J (2009) Selectivity and antimicrobial action of bovine lactoferrin derived peptides against wine lactic acid bacteria. Food Microbiol 26:340-346

41. Garcia-Ruiz A, Bartolome B, Martinez-Rodriguez AJ, Pueyo E, Martin-Alvarez PJ, Moreno-Arribas MV (2008) Potential of phenolic compounds for controlling lactic acid bacteria growth in wine. Food Control 19:835-841 